\title{
Guiding workplace learning in vocational education and training: a literature review

\author{
Susanna Mikkonen ${ }^{1}$, Laura Pylväs ${ }^{1}$, Heta Rintala ${ }^{2}$, Petri Nokelainen ${ }^{2^{*}}$ (1) and Liisa Postareff ${ }^{3}$
}

*Correspondence:
petri.nokelainen@tut.fi
${ }^{2}$ Industrial Information
Management Laboratory,
Tampere University
of Technology, Tampere,
Finland
Full list of author information
is available at the end of the
article

${ }^{*}$ Correspondence: petri.nokelainen@tut.f Management Laboratory, Tampere University Finland article

\begin{abstract}
This review provides an overview of the empirical research concerning guidance in the context of vocational education and training (VET). The study examines practices, providers and supporting and hindering factors related to guidance and learning at the workplace. After the inclusion/exclusion process, the final number of research articles included in this review is 18 . Results show strong evidence for the collective nature of workplace guidance, with the entire work community providing learners with guidance and assistance. Guidance provided to VET students at workplaces seems to relate strongly to the activities of the members of communities of practice. Guidance provided by the members of communities of practice opens up opportunities for learners to participate in collective practices by gradually assuming more responsibility and more demanding tasks as their skills develop. The learner's self-regulative skills, such as responsibility and the ability to take the initiative and to actively seek guidance, affect how guidance is afforded to him/her in the work community during training. Furthermore, these skills may also determine the learner's prospects for developing expertise in future workplaces.
\end{abstract}

Keywords: Guidance, Workplace learning, Apprenticeship education, Literature review

\section{Background}

Interest in workplace learning has grown in recent decades due to the changing character of work and the acknowledgement of the workplace as a learning environment (e.g. Fuller and Unwin 2003, 2011; Illeris 2003). In the context of vocational education and training (VET), apprenticeships and work-based learning have been promoted (e.g., European Commission 2015). The aim of this review is to provide an overview of guidance and learning at the workplace in the context of vocational education and training. In VET programmes, theoretical studies in vocational institutions and practical training at workplaces should be considered complementary providing different kind of opportunities for learning (Aarkrog 2005). The connective model of Guile and Griffiths (2001) emphasises close collaboration between vocational institutions and workplaces in creating an ideal way to organize workplace learning for VET students. The model underlines that the context and the access provided to artefacts and people influences learning, while opportunities to participate in forms of social practice with different communities

(C) The Author(s) 2017. This article is distributed under the terms of the Creative Commons Attribution 4.0 International License (http://creativecommons.org/licenses/by/4.0/), which permits unrestricted use, distribution, and reproduction in any medium, provided you give appropriate credit to the original author(s) and the source, provide a link to the Creative Commons license, and indicate if changes were made. 
of practice are central to learning. Learners require opportunities to recontextualise their theoretical and practical knowledge in new contexts in order to create new knowledge and practices (Griffiths and Guile 2003). Thus, different kinds of practices, such as assistance from more experienced others and boundary crossing facilitate learning within and between the different contexts of education and work (Akkerman and Bakker 2011, 2012; Griffiths and Guile 2003). Research has shown that close collaboration between students, workplaces and vocational institutions benefits learning (Savoie-Zajc and Dolbec 2003; Virtanen and Tynjälä 2008; Virtanen et al. 2014).

In the field of workplace learning, sociocultural theories consider learning as an ongoing, both an individual and social process of participation shaped by social, organizational, cultural and other contextual factors (Hager 2013). Tynjälä (2013) 3-P model of workplace learning acknowledges the sociocultural environment as a context that defines the possibilities and constraints of workplace learning. According to the model, there are three basic components in the learning phenomenon. The presage component includes both learner factors and learning context which relates to work organization and its features including organisation of work, partnerships and networks. Tynjälä (2013) points out that these factors do not affect the learning process directly but rather through the learner's interpretation of the factors, which is in line with the constructivist's view of learning. The process component encompasses the learning activities through participation, collaboration and interaction, whereas the product component includes diverse learning outcomes (Tynjälä 2013). Billett (2002a, b) notes that participation in social practices is regulated by the workplace affordances and shapes both the learning process and the outcome. However, eventually an individual, the learner, can choose whether or not to engage in the process of learning.

As a process workplace learning is often considered incidental or informal, even if it could instead be seen as non-formal with different levels of intention to learn, including implicit, reactive and deliberate learning (Eraut 2004). Alternatively, one can regard all learning experiences as intentional because they aim at ensuring the continuity of social and work practices (Billett 2002b). Ethnographic field studies on apprenticeships by Lave and Wenger (1991) suggest that learning happens in everyday interactions and through participation in communities of practice. However, the theory by Lave and Wenger (1991) has also been opposed as it neglects guidance and formal education, and is based on the idea that skills, knowledges and practices are passed on to novices. By doing this, the theory ignores the reciprocity of learning and the continuation of learning even after a full membership in a community of practice has been obtained (Fuller et al. 2005). Tanggaard (2005) states that studies on apprenticeship often describe apprentices gradually acquiring greater responsibilities and widening participation in new stages of production, but not much is said about how new skills are taught or didactically instructed. Tanggaard continues that teaching at the workplace is loosely organised as a possibility for the apprentice to receive help and get advice in the daily work situations, and takes place in connection with various social relations. Nielsen (2008) concludes that important educational interventions and instructional processes are used at workplaces, but they are not necessarily recognised as such.

The use of various terms related to pedagogical practices or interventions taking place at workplaces is heterogeneous and oftentimes incoherent. The concept of guidance 
is often used in the context of workplace learning (e.g. Billett 2002b, 2014). Coaching, tutoring and mentoring are similar activities which all have the underlying intention of providing support and encouraging the professional development and learning of individuals. However, the lines between the concepts of guidance, coaching, tutoring and mentoring are blurred although the underlying meaning of these concepts differ from each other (see Gallacher 1997; Wisker et al. 2013). Coaching refers to a process which occurs between peers or colleagues and is rather structured and systematic in nature (Gallacher 1997). Coaching has a rather narrow focus as it often concerns a specific problem, and the role of the coach is to help the coachee to define and overcome this problem (Wisker et al. 2013). Tutoring refers to offering support given by a responsible person within the organisation to a person, usually a novice, related to more practical matters. Tutors have a key role in acting between the institution and the individual (Wisker et al. 2013). Mentoring is about monitoring and assisting an individual's development over a longer period of time, and mentoring can take the form of individual, group or peer mentoring (Wisker et al. 2013). Mentoring is also a term frequently used in higher education context to refer to personal support, career development and introduction to professional networks (Pearson and Kayrooz 2004). Another concept often adopted in the higher education context is supervision, which takes place when individuals have a long-term task, i.e. a thesis or a project. Similar with coaching and mentoring, supervising aims at enabling and supporting individuals to develop their skills and achieve tasks. However, supervision has a broader scope in that it often includes working alongside with the individual, as well as negotiation and dialogue, to enable the person to take an active role in developing the skills and processes. Thus, giving answers and fixed solutions is avoided in supervision (Wisker et al. 2013). Supervision has traditionally referred to a master-apprentice relationship, but lately the role of the academic community in supervision has been emphasized (Mainhard et al. 2009). Furthermore, good supervision is characterised by an emphasis on the learning processes and general work processes instead of the product (see Pearson and Brew 2002; Vehviläinen and Löfström 2016).

In this study, we use the term guidance to describe the support that members of the work community and teachers from vocational institutes provide for students (see also Virtanen and Tynjälä 2008). We also utilize Billett (2002b) division of direct and indirect guidance to describe various guidance practices at the workplace. The social and physical environment of the workplace provides indirect guidance that is accessed in everyday work activities when the physical arrangements assist workplace learning and provide access to observing and listening more experienced coworkers and peers (Billett 2002b). As much of what one must learn cannot be learnt through trial and error alone, intentional workplace learning strategies, such as guided learning, are necessary to assist an individual in developing procedures and concepts required for shared practice (Billett 2002b). Direct guidance refers to close guidance and direct interaction between more experienced workers and learners (Billett 2002b). Billett (2002b) concludes that workplace pedagogic practices comprise three interdependent planes of guided engagement with work activities. The first plane includes everyday participation at work and the organizing of access to knowledge through observing and listening, but also by engaging in tasks of increasing accountability and understanding the goals of the required 
performance. The second plane comprises direct guidance and intentional learning strategies that are directed towards developing and promoting values, procedures, and understandings. Guided learning at work includes the use of modeling, coaching and scaffolding as well as other techniques to develop understanding and to engage learners in learning for themselves. The third plane of guided learning focuses on extending the adaptability of learners' knowledge to new situations and circumstances. The use of questioning, problem-solving, dialogues and group discussions aim at assisting learners to assess the scope and the limits of their knowledge and the possibilities of its transfer to new situations.

This literature review presents an overview of the empirical research on guidance and learning at the workplace in the context of vocational education and training. The goal is to provide a holistic view on how guidance actualizes at the workplace by identifying practices, providers and supporting and hindering factors related to guidance and learning at the workplace. The research questions are the following:

(RQ1) What kind of guidance practices are used at the workplace?

(RQ2) Who provides guidance at the workplace?

(RQ3) Which factors of guidance support or hinder learning at the workplace?

In this article, we will next describe our literature review method and the studies selected for this review. In the result section, we seek to answer our three research questions based on the articles selected for this review. In the conclusions and discussion, we will further discuss the empirical findings from the selected studies and provide suggestions for future research. We will also discuss some limitations of this study.

\section{Method and overview of the studies selected for the review}

The research method of this study is a literature review. The review type for this study is a mapping review (Grant and Booth 2009). A mapping review aims at mapping out and categorizing existing literature on a particular topic. Mapping reviews characterize the quantity and quality of literature and aim at identifying gaps in research literature from which to commission further research. For the literature review, we collected data by searching electronic databases to identify relevant studies. Search terms included guidance, counselling, supervision, mentoring, coaching, instruction, scaffolding, modeling, explanation, reflection and explorations in combination with the terms apprenticeship, workplace learning, on-the-job learning, work-based, vocational training and vocational education. In addition to searching through electronic databases, we manually searched the archives of journals focusing on workplace learning and vocational education.

In the initial article search, we searched for peer-reviewed articles from the ERIC (Education Resources Information Center) and Education Research Complete databases. The article search yielded 1209 articles from the ERIC database and 1136 articles from Education Research Complete (2275 all together after duplicates removed). We then started to limit the number of articles to those relevant to our study according to our specific inclusion and exclusion criteria. First, we only included studies published between 1995 and 2015 with full-text available and the language of the publication being English. This left us with 489 articles. We read the abstracts of these articles, and also 
the full texts in case the abstracts didn't provide enough information for decision making. In the process, we included empirical studies focusing on guidance in the context of workplace learning within the vocational education and training system. We therefore excluded studies focusing on mentoring employees in corporate settings. We did include studies on guided learning at the workplace in apprenticeship education and during onthe-job learning periods in vocational education, but excluded studies in the higher education context. After the first round of the inclusion/exclusion process, we searched the reference lists of the articles selected for the review to identify additional relevant studies. The Google Scholar database was also included in the search at the end of the process, but no new articles were found.

Although the search yielded a decent amount of articles, a minimum number of them actually discussed guided learning at the workplace. Most of the articles excluded from this review covered workplace learning (not guidance), mentoring programs in enterprises or guidance on levels of education other than vocational education and training (e.g. higher education). After the inclusion/exclusion process, the final number of research articles included in the review was 18 (see Table 1). Two researchers participated in both setting the inclusion/exclusion criteria and in discussing the articles selected for the study. Other scholars (Nielsen 2008; Tanggaard 2005) have previously noted the tendency in research on apprenticeship education to overlook issues of guidance at the workplace. The literature search process for this article further supports this finding: studies related to the guidance of VET students at workplaces are few indeed.

The data was collected and studies were assessed using a data extraction matrix, which included information on sample size, study design and results related to guidance and workplace learning. The assembly of the data was guided by the three research questions presented in "Background". We arranged the collected data to identify claims made in the literature. Two researchers further thematized the claims into broader categories, first independently and then together, by comparing and discussing the claims until they reached consensus. Based on the theoretical background and literature surveyed, we then listed the factors of guidance that support or prevent learning at workplaces in a table. We also identified practices that individuals and groups at workplaces typically use to provide learners with guidance. The following sections will present and further discuss the findings in greater detail.

In Table 1, we have presented the 18 articles selected for this study. The studies cover various training programmes within the vocational education and training framework. In nine articles (articles 1, 3, 4, 5, 6, 7, 10, 13 and 14), the training programmes could be described as more traditional apprenticeship programmes with the majority of the learning taking place at the workplace. In nine articles (articles 2, 8, 9, 11, 12, 15, 16, 17 and 18), the vocational training programmes involved both school-based and workbased learning, with variation in the length of the on-the-job learning periods.

Total number of participants in the 18 reviewed articles was 3485, of which 681 participated in qualitative and 2804 in quantitative studies. Qualitative methods dominated the sample, as they were applied in 10 studies between 1999-2015. Three studies (2008-2014) applied quantitative methods and four mixed-method studies (2000-2011) applied both qualitative and quantitative methods. Participation selection criteria was explicit in most of the reviewed articles (16), but only 11 articles described participants' 
Table 1 Overview of the studies

\begin{tabular}{|c|c|c|c|c|}
\hline Study & Sample & Country & Data & Method \\
\hline 1. Chan (2014) & 90 apprentices & New Zealand & Interviews & Qualitative \\
\hline $\begin{array}{l}\text { 2. Collin and Valleala } \\
\text { (2005) }\end{array}$ & $\begin{array}{l}18 \text { design and develop- } \\
\text { ment engineers, } \\
15 \text { youth workers }\end{array}$ & Finland & $\begin{array}{l}\text { Observations } \\
\text { Interviews }\end{array}$ & Qualitative \\
\hline $\begin{array}{l}\text { 3. Corney and du Ples- } \\
\text { sis (2010) }\end{array}$ & 106 male apprentices & Australia & $\begin{array}{l}\text { Questionnaire with scales: } \\
\text { Mentoring Relationship } \\
\text { Scale (Scandura and } \\
\text { Ragins 1993), } 3 \text { subscales: } \\
\text { Psychosocial support } \\
\text { Career development } \\
\text { Role modelling }\end{array}$ & Quantitative \\
\hline $\begin{array}{l}\text { 4. Evanciew and } \\
\text { Rojewski (1999) }\end{array}$ & $\begin{array}{l}\text { Three apprentices, } 3 \\
\text { mentors }\end{array}$ & $\begin{array}{l}\text { United States } \\
\text { of America }\end{array}$ & $\begin{array}{l}\text { Observations } \\
\text { Field notes } \\
\text { Interviews } \\
\text { Document analysis }\end{array}$ & Qualitative \\
\hline 5. Filliettaz (2011) & $\begin{array}{l}\text { Cohort of about } 40 \\
\text { apprentices }\end{array}$ & Switzerland & $\begin{array}{l}\text { Observations } \\
\text { Audio-video recordings }\end{array}$ & Qualitative \\
\hline $\begin{array}{l}\text { 6. Fuller and Unwin } \\
\text { (2004) }\end{array}$ & $\begin{array}{l}29 \text { apprentices, } 29 \\
\text { workers }\end{array}$ & UK & $\begin{array}{l}\text { Interviews } \\
\text { Learning logs } \\
\text { Surveys } \\
\text { Observation }\end{array}$ & Mixed methods \\
\hline 7. Gurtner et al. (2011) & 19 apprentices & Switzerland & $\begin{array}{l}\text { Audio-recordings on } \\
\text { mobile devices }\end{array}$ & Mixed methods \\
\hline $\begin{array}{l}\text { 8. Koskela and Palukka } \\
\text { (2011) }\end{array}$ & $\begin{array}{l}\text { Stage } 1: 9 \text { trainees, } 6 \\
\text { trainers } \\
\text { Stage } 2: 2 \text { trainees, } 4 \\
\text { trainers }\end{array}$ & Finland & $\begin{array}{l}\text { Observations } \\
\text { Video recordings }\end{array}$ & Qualitative \\
\hline 9. Nielsen (2008) & $\begin{array}{l}\text { Four apprentices, } 2 \text { jour- } \\
\text { neymen, } 1 \text { master, } \\
12 \text { apprentices (from } 3 \\
\text { group interviews) }\end{array}$ & Denmark & $\begin{array}{l}\text { Observations } \\
\text { Interviews }\end{array}$ & Qualitative \\
\hline 10. Onnismaa (2008) & 27 students & Finland & Interviews & Qualitative \\
\hline 11. Reegård (2015) & $\begin{array}{l}11 \text { apprentices, } 7 \\
\text { managers }\end{array}$ & Norway & $\begin{array}{l}\text { Interviews } \\
\text { Observations }\end{array}$ & Qualitative \\
\hline $\begin{array}{l}\text { 12. Savoie-Zajc and } \\
\text { Dolbec (2003) }\end{array}$ & $\begin{array}{l}175 \text { students, teachers, } \\
\text { stakeholders }\end{array}$ & Canada & $\begin{array}{l}\text { Three questionnaires: } \\
\text { Expectations } \\
\text { Learning } \\
\text { Overall appraisal } \\
\text { Interviews }\end{array}$ & Mixed methods \\
\hline 13. Smith (2000) & $\begin{array}{l}389 \text { apprentices, } 8 \\
\text { apprentices }\end{array}$ & Australia & $\begin{array}{l}\text { Questionnaire Canfield } \\
\text { Learning Styles Inventory, } \\
\text { CSLI (Canfield 1980), } 16 \\
\text { subscales } \\
\text { Interviews }\end{array}$ & Mixed methods \\
\hline 14. Tanggaard (2005) & 10 male apprentices & Denmark & $\begin{array}{l}\text { Interviews } \\
\text { Observations }\end{array}$ & Qualitative \\
\hline 15. Wegener (2014) & $\begin{array}{l}\text { More than a } 100 \\
\text { students, teachers and } \\
\text { supervisors }\end{array}$ & Denmark & $\begin{array}{l}\text { Field observations } \\
\text { Interviews }\end{array}$ & Qualitative \\
\hline $\begin{array}{l}\text { 16. Winters et al. } \\
\text { (2009) }\end{array}$ & $\begin{array}{l}24 \text { students, } 15 \text { teachers, } \\
18 \text { mentors }\end{array}$ & Netherlands & Conversation & Qualitative \\
\hline $\begin{array}{l}\text { 17. Virtanen and } \\
\text { Tynjälä (2008) }\end{array}$ & 531 vocational students & Finland & $\begin{array}{l}\text { Questionnaire (Tynjälä and } \\
\text { Virtanen 2005; Virtanen } \\
\text { and Tynjälä 2006) }\end{array}$ & Quantitative \\
\hline $\begin{array}{l}\text { 18. Virtanen et al. } \\
\text { (2014) }\end{array}$ & $\begin{array}{l}1603 \text { vocational stu- } \\
\text { dents }\end{array}$ & Finland & Questionnaire & Quantitative \\
\hline
\end{tabular}


demographic data (e.g., age, gender, work experience). Further, only six articles mentioned voluntary participation. Most common data collection method was interview (10 articles), but also observation ( 8 articles) and surveys ( 5 articles) were applied. Nine of the articles applied individual level data collection (interviews and surveys), five applied both individual and group level data collection (observations and focus group interviews or conversations), and two articles were based on group level data.

\section{Results}

(RQ1) What kind of guidance practices are used at the workplace?

In this chapter, we look into how guidance is actualized at workplaces and seek to identify the kinds of guidance practices typically used at the workplace (RQ1). The articles selected for this literature review introduce a variety of practices through which guidance is provided for students and apprentices at workplaces (Table 2).

In five articles out of 18 (Evanciew and Rojewski 1999; Filliettaz 2011; Koskela and Palukka 2011; Onnismaa 2008; Tanggaard 2005), guidance was described as a process during which more experienced workers and novices work together: Novices work under the surveillance of experts, while experts monitor the work of the students and provide help if needed. The help provided by experts can involve for example hints and clues on how to successfully complete a task (Evanciew and Rojewski 1999), providing instructions and making sure that students have understood them (Filliettaz 2011), and asking questions or providing hints that allow trainees to make independent assessments as to what to do next (Koskela and Palukka 2011). Sometimes the trainers can also give somewhat more direct orders about which task should be performed next (Koskela and Palukka 2011). Tanggaard (2005) describes the help provided by experts as a kind of frustration control that helps when the apprentices cannot cope on their own.

Five articles described guidance as an activity of explanation (Collin and Valleala 2005; Evanciew and Rojewski 1999; Koskela and Palukka 2011; Onnismaa 2008; Tanggaard 2005). Evanciew and Rojewski (1999) state that apprentices benefit from their mentors' descriptions of the 'tricks of the trade' and thereby gain access to information unavailable at school. The process of explanation can also be seen as involving the sharing of tacit

Table 2 Guidance practices manifested at the workplace

\begin{tabular}{|c|c|c|}
\hline Guidance practices & Number of articles & References \\
\hline $\begin{array}{l}\text { Experts and novices working together } \\
\text { (experts monitoring, providing help if } \\
\text { needed) }\end{array}$ & 5 & $\begin{array}{l}\text { Evanciew and Rojewski (1999), Filliettaz } \\
\text { (2011), Koskela and Palukka (2011), Onnis- } \\
\text { maa (2008), Tanggaard (2005) }\end{array}$ \\
\hline $\begin{array}{l}\text { Explanations (providing information, cat- } \\
\text { egorisation, transferring tacit knowledge) }\end{array}$ & 5 & $\begin{array}{l}\text { Collin and Valleala (2005), Evanciew and } \\
\text { Rojewski (1999), Koskela and Palukka } \\
\text { (2011), Onnismaa (2008), Tanggaard (2005) }\end{array}$ \\
\hline $\begin{array}{l}\text { Reflection (conversations, discussions, } \\
\text { feedback) }\end{array}$ & 5 & $\begin{array}{l}\text { Filliettaz (2011), Smith (2000), Wegener } \\
\text { (2014), Winters et al. (2009), Virtanen and } \\
\text { Tynjälä (2008) }\end{array}$ \\
\hline Scaffolding and fading & 4 & $\begin{array}{l}\text { Evanciew and Rojewski (1999), Filliettaz } \\
\text { (2011), Nielsen (2008), Tanggaard (2005) }\end{array}$ \\
\hline Observation and demonstrations & 3 & $\begin{array}{l}\text { Evanciew and Rojewski (1999), Smith (2000), } \\
\text { Tanggaard (2005) }\end{array}$ \\
\hline Independent work and experimentation & 3 & $\begin{array}{l}\text { Evanciew and Rojewski (1999), Reegård } \\
\text { (2015), Smith (2000) }\end{array}$ \\
\hline
\end{tabular}


knowledge with newcomers at the workplace. The transfer of tacit knowledge seems most efficient when more experienced professionals work together with inexperienced apprentices (Koskela and Palukka 2011; Onnismaa 2008). Collin and Valleala (2005) also describe the process of categorization, which involves 'unpacking' work-related categories, with experienced workers who explain which topics certain categories cover (e.g. confidential information). Categorization is a central activity of socializing new workers into the workplace and contributes to the building of mutual understanding about workrelated categories.

Of the 18 articles, five saw guidance as involving conversations and discussions with others as well as reflection of one's learning (Filliettaz 2011; Smith 2000; Winters et al. 2009; Wegener 2014; Virtanen et al. 2014). Virtanen and Tynjälä (2008) define selfassessment as students evaluating their own performance. Discussing and assessing learning, however, occurs more frequently in the presence of others. According to Virtanen and Tynjälä's study (2008), discussions with other employees are the most widely used form of guidance during on-the-job learning periods of VET students. Smith (2000) reports that discussions with fellow workers and supervisors are in frequent use at workplaces and help apprentices develop their knowledge. Filliettaz (2011) describes more experienced workers giving systematic feedback to apprentices and thus inviting apprentices to engage in conversations. Winters et al. (2009) and Virtanen et al. (2014) also report on somewhat more formal training discussions that involve teachers from vocational institutes and that include discussions with experts about the meaning of students' experiences during studies. Winters et al. (2009) however notes, that during the discussions involving students, teachers and workplace mentors, the potential to engage students in reflecting on their experiences was not utilised. Similarly, Wegener (2014) notes that discussions involving teachers, students and supervisors don't necessarily stimulate reflection, as students tend to view discussions as test situations and feel like they need to provide "right" answers, instead of more freely discussing their experiences. Instead of formal situations, students tend to initiate reflection at everyday interactions at the workplace, where reflection is not the object per se. However, according to Wegener, educators have difficulties acting on these initiatives.

In four articles out of 18, guidance was described as a process of scaffolding and fading (Evanciew and Rojewski 1999; Filliettaz 2011; Nielsen 2008; Tanggaard 2005). Nielsen 2008) defines scaffolding as "a process whereby beginners in a profession are supported by experienced workers so as to improve their basis for participating in a social practice". Through the scaffolding process, newcomers are introduced to new areas of the profession and eventually invited to take over more responsibility in the production process. Scaffolding includes the gradual withdrawal of support as the beginner's skills improve (fading). The articles covered in this review described the apprentices as assuming increasing responsibility and enjoying progressive recognition as legitimate and trustworthy members of the work community. Scaffolding can thus be seen as supporting the identity formation of apprentices (Filliettaz 2011; Nielsen 2008). Nielsen (2008) states that scaffolding can also serve to communicate bodily know-how (non-verbal scaffolding) to apprentices. A significant part of what is being learned in craft production requires for the apprentice to develop a bodily sense of the products. Scaffold instruction enables apprentices to observe and touch the product, and together with the master 
to evaluate its quality. Tanggaard (2005) describes the typical scaffolding situations as often representing a more asymmetrical relationship between the experienced and the not so experienced workers, which can sometimes lead to the apprentice not being critical towards existing practices.

Three articles describe the observation of demonstrations by more experienced workers and supervisors as central to guidance processes at the workplace (Evanciew and Rojewski 1999; Smith 2000; Tanggaard 2005). Smith (2000) distinguishes between worker observations and environment observations. Worker observation can be described as "structured observation of the process being demonstrated by a fellow worker". Smith argues that apprentices highly appreciate demonstrations as a method of learning. Similarly, both Evanciew and Rojewski (1999) and Tanggaard (2005) state that apprentices found observing the work and demonstrations by more experienced workers as valuable and beneficial for their learning. However, according to, Smith (2000) environment observation ("unstructured observation of the workplace to identify visual cues from artefacts, objects, and physical arrangements") was not seen as an effective way to learn by the apprentices, nor was it appreciated by the supervisors, who rather saw it as a waste of time.

Three articles mentioned allowing independent work and encouraging students to experiment and explore on their own as part of guidance activities (Evanciew and Rojewski 1999; Reegård 2015; Smith 2000). Reegård (2015) describes the managers quickly introducing apprentices to work and trusting them with a lot of responsibility and autonomy from early on. On the one hand, this was seen as a deliberate pedagogical strategy. On the other hand, independency could be seen as a signal of poor formal training awareness and lack of resources available for guidance. Smith (2000) also describes the activity of practicing as a form of independent work of students. Hairdressers for example were expected to practice with dummy heads before treating the hair of customers. Evanciew and Rojewski (1999) mention that trainers sometimes encourage apprentices to attempt or explore a task on their own before requesting help from their trainers. The use of exploration, however, is rare. Smith (2000) states that the use of exploration is highly valued by the apprentices but often limited and not encouraged by the workplaces because of production and safety issues. Trials and experimentation outside of established work methods at the workplace is discouraged.

(RQ2) Who provides guidance at the workplace?

In this chapter, we seek to identify the providers of guidance at the workplace. We are interested in recognizing the people or groups of people who are involved in the process of providing guidance for students. The results of this chapter are summarized in Table 3.

The research identifies people or groups of people as providers of guidance at the workplace. Interestingly, of the 18 articles featured in this paper, only two (Koskela and Palukka 2011; Savoie-Zajc and Dolbec 2003) mention designated workplace trainers as the only ones responsible for guiding learners. Other articles highlight the more collective nature of workplace guidance and identify different groups of people as providing guidance for learners.

Of the 18 articles, ten view workplace guidance from a more collective perspective and claim that nominated trainers are not the only ones providing learners with guidance 
Table 3 Providers of guidance at work

\begin{tabular}{|c|c|c|}
\hline Providers of guidance & Number of articles & References \\
\hline $\begin{array}{l}\text { The entire work community (including } \\
\text { designated trainers, fellow workers and } \\
\text { employers, clients) }\end{array}$ & 10 & $\begin{array}{l}\text { Chan (2014), Collin and Valleala (2005), } \\
\text { Corney and du Plessis (2010), Evanciew } \\
\text { and Rojewski (1999), (Gurtner et al. 2011), } \\
\text { Onnismaa (2008), Reegård (2015), Smith } \\
\text { (2000), Tanggaard (2005), Wegener (2014) }\end{array}$ \\
\hline Peers & 7 & $\begin{array}{l}\text { Corney and du Plessis (2010), Filliettaz } \\
\text { (2011), Fuller and Unwin (2004), Gurtner } \\
\text { et al. (2011) Nielsen (2008), Smith (2000), } \\
\text { Tanggaard (2005) }\end{array}$ \\
\hline Teachers from vocational institutes & 5 & $\begin{array}{l}\text { Corney and du Plessis (2010), Wegener } \\
\text { (2014), Winters et al. (2009), Virtanen and } \\
\text { Tynjälä (2008), Virtanen et al. (2014) }\end{array}$ \\
\hline Designated workplace trainers & 2 & $\begin{array}{l}\text { Koskela and Palukka (2011), Savoie-Zajc } \\
\text { and Dolbec (2003) }\end{array}$ \\
\hline
\end{tabular}

(Chan 2014; Collin and Valleala 2005; Corney and du Plessis 2010; Evanciew and Rojewski 1999; Gurtner et al. 2011; Onnismaa 2008; Reegård 2015; Smith 2000; Tanggaard 2005; Wegener 2014). Other members of the work community are also involved in providing guidance for newcomers when they share workplace situations. Although learners are usually assigned a designated workplace trainer, other colleagues, experts and workplace managers also interact with them while they engage in their work tasks. Filliettaz (2011) refers to this as distributed or collective guidance. Tanggaard (2005) claims that apprentices often develop a significant relationship with a person other than their designated trainer as an instructor, provided that person is readily available for guidance. Apprentices often build their own networks for learning and choose instructors with whom they feel comfortable.

Seven of the 18 articles mention that guidance can also come from fellow learners (Corney and du Plessis 2010; Filliettaz 2011; Fuller and Unwin 2004; Gurtner et al. 2011; Nielsen 2008; Smith 2000; Tanggaard 2005). Corney and du Plessis (2010) refer to this as strengths-based natural mentoring or peer mentoring, which uses the supportive networks young people naturally build in their work contexts. Peer mentoring involves a more mutual approach and is based on reciprocal relationships and equality. Tanggaard (2005) uses the term 'symmetrical instruction' to describe situations in which apprentices with nearly the same level of competence guide and instruct each other. He claims that symmetrical instruction helps apprentices to develop critical attitudes towards the work, in contrast to situations of asymmetrical instruction, where apprentices might imitate more experienced workers without questioning how they do things. Asymmetrical instruction also opens up opportunities for reflection as well as even technical innovations and new ideas through cooperation with apprentices. Fuller and Unwin (2004) note that apprentices also spend significant amounts of time helping other workers, which challenges the traditional novice-expert dichotomy and suggests that apprentices can also utilize their prior experience and learning to provide guidance for others.

Five articles argue that teachers from vocational institutions sometimes also participate in guiding the workplace learning of the VET students (Corney and du Plessis 2010; Wegener 2014; Winters et al. 2009; Virtanen and Tynjälä 2008; Virtanen et al. 2014). The process of guidance clearly involves teachers, especially in planning and evaluating 
learners' workplace learning periods. Although workplace trainers are primarily responsible for guiding their students, teachers also visit workplaces during on-the-job learning periods and provide guidance for their students through discussions. Discussions between students and teachers are vital pedagogical elements of workplace learning that help to integrate school learning and workplace learning. Setting goals for workplace learning periods with teachers shows the student that he/she must learn at least some vocational qualifications at the workplace. Wegener (2014) notes that the different kind of didactical practices may also lead to conflicts between teachers and workplace supervisors.

\section{(RQ3) Which factors of guidance support or hinder learning at the workplace?}

In this chapter, we have classified the findings on guidance and work environment into four categories: (1) learner factors, (2) direct guidance, (3) indirect guidance and learning context, and (4) connectivity. Table 4 presents the summary of the supporting factors and Table 5 shows an overview of the hindering factors related to guidance and learning in the workplace.

\section{Learner factors}

The studies selected for this review show that apprentices are often required to work autonomously and receive support only if necessary. Apprentices are largely responsible for their own learning and must often initiate activities to develop their skills by themselves (Gurtner et al. 2011; Reegård 2011; Savoie-Zajc and Dolbec 2003; Smith 2000; Tanggaard 2005). Such situations often push learners to develop the self-regulative skills (Reegård 2015; Virtanen and Tynjälä 2008; Virtanen et al. 2014) and strong social skills (Evanciew and Rojewski 1999; Savoie-Zajc and Dolbec 2003) that are essential to initiating requests for guidance. The work community may however view excessive requests for guidance or being a slow learner as tiresome behavior, which may lead to the discontinuation of the apprentice's training in the workplace (Gurtner et al. 2011; Nielsen 2008). Evanciew and Rojewski (1999) also report that apprenticeships are sometimes even terminated because of the apprentice's lack of appropriate social skills and work ethic, despite the trainer's failure to allocate sufficient time to teach these skills. The learner's deliberate career choice and previous work experience support motivation for and engagement in workplace learning (Chan 2014).

\section{Direct guidance}

Smith (2000) notes that the workplace and workplace management can also support guidance by securing adequate resources for the workplace trainer. The trainer should always be provided with sufficient time to make space in the production schedule for training and supervision activities. Support from the workplace for the workplace trainer is essential in order to train and guide apprentices to fulfill a legitimate role in the work community. A major hindrance to the success of workplace guidance comes from a work community that fails to commit to guiding learners.

Support from the designated workplace trainer is an important feature of guidance that has been shown to support workplace learning. First, a close personal relationship with the workplace trainer has proved to be a valuable resource for apprentices. 
Table 4 Factors supporting guidance

\begin{tabular}{|c|c|c|c|}
\hline Factors & Supporting factors & $\begin{array}{l}\text { Number } \\
\text { of articles }\end{array}$ & References \\
\hline \multirow[t]{4}{*}{ Learner factors } & Initiativeness, responsibility & 6 & $\begin{array}{l}\text { Gurtner et al. (2011), Reegård } \\
\text { (2015), Savoie-Zajc and Dolbec } \\
\text { (2003), Smith (2000), Tanggaard } \\
\text { (2005), Wegener (2014) }\end{array}$ \\
\hline & Self-regulation & 3 & $\begin{array}{l}\text { Reegård (2015), Virtanen and Tyn- } \\
\text { jälä (2008), Virtanen et al. (2014) }\end{array}$ \\
\hline & Strong social skills & 2 & $\begin{array}{l}\text { Evanciew and Rojewski (1999), } \\
\text { Savoie-Zajc and Dolbec (2003) }\end{array}$ \\
\hline & $\begin{array}{l}\text { Prior experience, deliberate } \\
\text { career choice }\end{array}$ & 1 & Chan (2014) \\
\hline \multirow[t]{8}{*}{ Direct guidance } & $\begin{array}{l}\text { Supportive relationship with } \\
\text { a trainer }\end{array}$ & 4 & $\begin{array}{l}\text { Chan (2014), Evanciew and Rojew- } \\
\text { ski (1999), Tanggaard (2005), } \\
\text { Virtanen et al. (2014) }\end{array}$ \\
\hline & $\begin{array}{l}\text { Time and resources provided } \\
\text { for guidance }\end{array}$ & 2 & Nielsen (2008), Smith (2000) \\
\hline & Various guidance methods & 2 & $\begin{array}{c}\text { Evanciew and Rojewski (1999), } \\
\text { Koskela and Palukka (2011) }\end{array}$ \\
\hline & $\begin{array}{l}\text { Trainer's ability to share knowl- } \\
\text { edge, stimulate questions }\end{array}$ & 2 & $\begin{array}{l}\text { Fuller and Unwin (2004), Gurtner } \\
\text { et al. (2011) }\end{array}$ \\
\hline & $\begin{array}{l}\text { Trainer's ability to produce } \\
\text { critical reflection }\end{array}$ & 1 & Onnismaa (2008) \\
\hline & $\begin{array}{l}\text { Pedagogical qualification, } \\
\text { formal training }\end{array}$ & 2 & Filliettaz (2011), Smith (2000) \\
\hline & Trainer's self-reflection & 1 & Koskela and Palukka (2011) \\
\hline & $\begin{array}{l}\text { Learner's tendency to select } \\
\text { trainer(s) }\end{array}$ & 1 & Tanggaard (2005) \\
\hline \multirow[t]{9}{*}{$\begin{array}{l}\text { Indirect guidance/learning } \\
\text { context }\end{array}$} & $\begin{array}{l}\text { Learner's participation, legiti- } \\
\text { mate, active role, agency }\end{array}$ & 9 & $\begin{array}{l}\text { Chan (2014), Collin and Valleala } \\
\text { (2005), Evanciew and Rojewski } \\
\text { (1999), Filliettaz (2011), Gurtner } \\
\text { et al. (2011), Koskela and Palukka } \\
\text { (2011), Nielsen (2008), Savoie- } \\
\text { Zajc and Dolbec (2003), Virtanen } \\
\text { et al. (2014) }\end{array}$ \\
\hline & $\begin{array}{l}\text { Learner's independent work, } \\
\text { increasing responsibility }\end{array}$ & 6 & $\begin{array}{l}\text { Evanciew and Rojewski (1999), } \\
\text { Filliettaz (2011), Gurtner et al. } \\
\text { (2011), Nielsen (2008), Reegård } \\
\text { (2015), Smith (2000) }\end{array}$ \\
\hline & $\begin{array}{l}\text { Supportive relationships with } \\
\text { various workers }\end{array}$ & 6 & $\begin{array}{l}\text { Chan (2014), Corney and du } \\
\text { Plessis (2010), Filliettaz (2011), } \\
\text { Savoie-Zajc and Dolbec (2003), } \\
\text { Smith (2000), Virtanen et al. } \\
\text { (2014) }\end{array}$ \\
\hline & $\begin{array}{l}\text { Sense of equality and com- } \\
\text { munity }\end{array}$ & 3 & $\begin{array}{l}\text { Collin and Valleala (2005), Fuller } \\
\text { and Unwin (2004), Reegård } \\
\text { (2015) }\end{array}$ \\
\hline & Reciprocal relationships & 3 & $\begin{array}{l}\text { Fuller and Unwin (2004), Nielsen } \\
\text { (2008), Onnismaa (2008) }\end{array}$ \\
\hline & $\begin{array}{l}\text { Support from significant } \\
\text { others }\end{array}$ & 2 & $\begin{array}{l}\text { Chan (2014), Corney and du Ples- } \\
\text { sis (2010) }\end{array}$ \\
\hline & $\begin{array}{l}\text { Learner's opinions and partici- } \\
\text { pation taken into account }\end{array}$ & 3 & $\begin{array}{l}\text { Onnismaa (2008), Reegård (2015), } \\
\text { Virtanen et al. (2014) }\end{array}$ \\
\hline & Task or team rotation & 3 & $\begin{array}{l}\text { Fuller and Unwin (2004), Savoie- } \\
\text { Zajc and Dolbec (2003), Virtanen } \\
\text { et al. (2014) }\end{array}$ \\
\hline & Peer relationships and support & 3 & $\begin{array}{l}\text { Chan (2014), Gurtner et al. (2011), } \\
\text { Tanggaard (2005) }\end{array}$ \\
\hline
\end{tabular}


Table 4 continued

\begin{tabular}{|c|c|c|c|}
\hline Factors & Supporting factors & $\begin{array}{l}\text { Number } \\
\text { of articles }\end{array}$ & References \\
\hline \multirow[t]{4}{*}{ Connectivity } & $\begin{array}{l}\text { Connectivity, integration of } \\
\text { theory and practice }\end{array}$ & 5 & $\begin{array}{l}\text { Onnismaa (2008), Savoie-Zajc and } \\
\text { Dolbec (2003), Winters et al. } \\
\text { (2009), Virtanen and Tynjälä } \\
\text { (2008), Virtanen et al. (2014) }\end{array}$ \\
\hline & $\begin{array}{l}\text { Personalization, individual } \\
\text { learning and guidance } \\
\text { needs }\end{array}$ & 4 & $\begin{array}{l}\text { Fuller and Unwin (2004), Onnis- } \\
\text { maa (2008), Smith (2000), } \\
\text { Virtanen et al. (2014) }\end{array}$ \\
\hline & $\begin{array}{l}\text { Explicit framework, clear rules } \\
\text { and roles }\end{array}$ & 3 & $\begin{array}{l}\text { Fuller and Unwin (2004), Onnis- } \\
\text { maa (2008), Smith (2000) }\end{array}$ \\
\hline & Identified goals & 2 & $\begin{array}{l}\text { Evanciew and Rojewski (1999), } \\
\text { Smith (2000) }\end{array}$ \\
\hline
\end{tabular}

Relationships with supportive mentors assist apprentices' workplace learning processes. Supportive workplace trainers trust their apprentices and enhance their self-esteem by praising them when they have carried out their work duties well (Chan 2014; Evanciew and Rojewski 1999). Instructional situations at workplaces have the potential to facilitate identity transformation and to provide access to new communities of practice (Koskela and Palukka 2011; Nielsen 2008). Instructional situations should include aspects of mutual recognition and identity formation (Nielsen 2008). Virtanen et al. (2014) state that the opportunity to receive individual guidance seems to be the most important factor in producing successful workplace learning outcomes. Tanggaard (2005) states that the potential for developing a personal relationship with the workplace trainer is greater at the workplace than at school. Workplace mentors are usually able to work longer and in greater detail, and thus to assist in learning, than teachers. However, according to, Chan (2014) even designated trainers sometimes lack personal engagement and commitment to guiding apprentices, which can lead to apprentices disengaging from their work. When workplace trainers fail to commit to guidance, apprentices receive insufficient support for their learning. Not being allowed to work independently and depending heavily on trainers keeps apprentices from becoming productive members of the work team. The degree of work autonomy can sometimes even depend on the work climate and the goodwill of the trainers (Savoie-Zajc and Dolbec 2003). The asymmetric power relationship between a learner and an instructor makes the instructor a role model, which can sometimes lead to uncritical imitation of poor habits (Tanggaard 2005). According to, Tanggaard 2005 apprentices often select their own network of trainers who best fit their personality. Trainers' unexpected reactions to requests for guidance limit initiative (Smith 2000).

The research underscores the importance of workplace trainers' pedagogical skills. Receiving support from a range of different workers at the workplace benefits apprentices' learning. The availability of workplace support from a broad range of workers, even those with no formal training role, benefits apprentices' learning (Chan 2014; Savoie-Zajc and Dolbec 2003; Tanggaard 2005). The trainer's pedagogical awareness and skills affect how the workplace serves as a learning environment. Pedagogical skills also influence the way in which experienced workers are able to share their knowledge and to provide opportunities for apprentices to participate in productive tasks at work (Filliettaz 2011). 
Table 5 Factors hindering guidance

\begin{tabular}{|c|c|c|c|}
\hline Factors & Hindering factors & Number of articles & References \\
\hline \multirow[t]{3}{*}{ Learner factors } & Tiresome behavior & 2 & $\begin{array}{l}\text { Gurtner et al. (2011), Nielsen } \\
\text { (2008) }\end{array}$ \\
\hline & Introvert behavior & 1 & Tanggaard (2005) \\
\hline & Poor work ethic & 1 & Evanciew and Rojewski (1999) \\
\hline \multirow[t]{5}{*}{ Direct guidance } & $\begin{array}{l}\text { Dependency and power } \\
\text { relationship }\end{array}$ & 2 & $\begin{array}{l}\text { Savoie-Zajc and Dolbec } \\
\text { (2003), Tanggaard (2005) }\end{array}$ \\
\hline & Redundant guidance & 1 & Nielsen (2008) \\
\hline & $\begin{array}{l}\text { Trainer's unpredictable reac- } \\
\text { tion to requests for help }\end{array}$ & 1 & Smith (2000) \\
\hline & $\begin{array}{l}\text { Lack of personal engage- } \\
\text { ment from the trainer }\end{array}$ & 1 & Chan (2014) \\
\hline & $\begin{array}{l}\text { Difficulties to interpret } \\
\text { abstract learning objec- } \\
\text { tives }\end{array}$ & 1 & Wegener (2014) \\
\hline \multirow[t]{6}{*}{$\begin{array}{l}\text { Indirect guidance/learning } \\
\text { context }\end{array}$} & $\begin{array}{l}\text { Lack of resources and focus } \\
\text { on productivity }\end{array}$ & 5 & $\begin{array}{l}\text { Gurtner et al. (2011), Nielsen } \\
\text { (2008), Onnismaa (2008), } \\
\text { Savoie-Zajc and Dolbec } \\
\text { (2003), Smith (2000) }\end{array}$ \\
\hline & $\begin{array}{l}\text { Power struggles, competi- } \\
\text { tion }\end{array}$ & 4 & $\begin{array}{l}\text { Filliettaz (2011), Fuller and } \\
\text { Unwin (2004), Nielsen } \\
\text { (2008), Onnismaa (2008) }\end{array}$ \\
\hline & Learner's marginal role & 4 & $\begin{array}{l}\text { Filliettaz (2011), Nielsen } \\
\text { (2008), Savoie-Zajc and } \\
\text { Dolbec (2003), Winters et al. } \\
\text { (2009) }\end{array}$ \\
\hline & Poor workplace support & 3 & $\begin{array}{l}\text { Chan (2014), Reegård (2015), } \\
\text { Smith (2000) }\end{array}$ \\
\hline & $\begin{array}{l}\text { Too much responsibility and } \\
\text { independence }\end{array}$ & 2 & $\begin{array}{l}\text { Gurtner et al. (2011), Reegård } \\
\text { (2015) }\end{array}$ \\
\hline & $\begin{array}{l}\text { Polarized or unevenly } \\
\text { distributed skills at the } \\
\text { workplace }\end{array}$ & 1 & Fuller and Unwin (2004) \\
\hline \multirow[t]{4}{*}{ Connectivity } & $\begin{array}{l}\text { Discrepancies between } \\
\text { learning environments }\end{array}$ & 3 & $\begin{array}{l}\text { Evanciew and Rojewski } \\
\text { (1999), Savoie-Zajc and } \\
\text { Dolbec (2003), Wegener } \\
\text { (2014) }\end{array}$ \\
\hline & $\begin{array}{l}\text { Unstructured training at the } \\
\text { workplace }\end{array}$ & 2 & $\begin{array}{l}\text { Chan (2014), Fuller and Unwin } \\
\text { (2004) }\end{array}$ \\
\hline & $\begin{array}{l}\text { Teachers having limited } \\
\text { available time }\end{array}$ & 2 & $\begin{array}{l}\text { Evanciew and Rojewski } \\
\text { (1999), Tanggaard (2005) }\end{array}$ \\
\hline & $\begin{array}{l}\text { Guidance taking place only } \\
\text { at the workplace, teachers } \\
\text { uninvolved }\end{array}$ & 1 & Virtanen et al. (2014) \\
\hline
\end{tabular}

Pedagogical skills can also appear as the ability to share knowledge or to raise questions and initiative (Fuller and Unwin 2004; Gurtner et al. 2011). Structured training for trainers is recommended to improve the overall quality of guidance at the workplace (Filliettaz 2011; Smith 2000). Virtanen and Tynjälä (2008) state that the pedagogical training of workplace trainers may also improve the critical thinking skills of VET students. Some researchers have noted, however, that workplace trainers show efficient training behaviors even without receiving formal training (Evanciew and Rojewski 1999; Koskela and Palukka 2011). Onnismaa (2008) states that workplace trainers are also challenged to take into account apprentices' prior experience and personal goals when guiding them. 
To facilitate learning, trainers can promote critical reflection, a central tenet of professional growth (Onnismaa 2008). Nevertheless, promoting reflection shouldn't become a way of leaving the learners on their own drawing their own interpretations and decisions (Wegener 2014). Trainers themselves must also engage in self-reflection and continuous observation of their interactions (Koskela and Palukka 2011).

\section{Indirect guidance and learning context}

The research underlines the importance of the ability of the communities of practice to provide apprentices with a supportive work atmosphere. A supportive learning environment includes a social and friendly atmosphere, positive attitudes towards helping apprentices, good workplace relationships among employees and meeting the apprentices' needs (Chan 2014; Smith 2000). When other workers are reluctant to help apprentices, there is no guarantee that guidance will be provided. A poor work climate at the workplace affects guidance and the learning affordances offered to the apprentices. If more experienced workers view the apprentice as a potential threat, they may seek to guard their own positions and may be less willing to encourage young people. Competition between workers and the fear of newcomers replacing the experienced workers may compel them not to share their expertise (Fuller and Unwin 2004; Nielsen 2008; Onnismaa 2008). Furthermore, Filliettaz (2011) states that power issues between workers affect the work climate and the learning affordances arising from work-productive tasks. Competition and conflicts between workers can place the apprentice in an uncomfortable position, where he/she must choose sides between workers and the people from whom he/she wishes to receive guidance. In such situations, apprentices bear the burden of always having to be the first to request assistance (Chan 2014; Reegård 2015; Smith 2000).

Several studies highlighted the problem concerning the lack of time and resources set aside for guidance (Gurtner et al. 2011; Nielsen 2008; Onnismaa 2008; Smith 2000). Guiding apprentices is not considered a priority; instead, production schedules sometimes become more important than instructing apprentices. When the main focus of the workplace is on preserving productivity, guidance seldom receives adequate attention (Savoie-Zajc and Dolbec 2003). This leads to apprentices having limited access to work operations and only being assigned simple work tasks that will not risk slowing production. Workplaces that focus mainly on productivity often fail to provide adequate conditions for workplace learning. Under these conditions, the apprentices' learning may remain limited, and the apprentices' legitimacy, weak (Fuller and Unwin 2004; Gurtner et al. 2011; Savoie-Zajc and Dolbec 2003; Smith 2000).

A sense of equality and community at work are important factors in learning a profession (Collin and Valleala 2005; Fuller and Unwin 2004). Non-hierarchical socialization processes and task equality, with all employees (including the managers) completing the same types of tasks, also fosters the integration of apprentices into work communities (Reegård 2015). Reciprocal relationships between all members of work communities help to build mutual trust and respect (Fuller and Unwin 2004; Nielsen 2008; Onnismaa 2008). Sharing knowledge and skills among colleagues regardless of age and status is essential to the development of expertise (Fuller and Unwin 2004; Onnismaa 2008). Relationships between peers at the workplace should also be encouraged, because peer 
learning provides guidance and support, especially if guidance is unavailable from other providers (Tanggaard 2005). Peer guidance is easily accessible and less risky than asking advice from experts, which explains its significance, especially in the beginning of the learning process (Gurtner et al. 2011). Moreover, support from family, friends, and significant others, is also considered important and affects learning at the workplace (Chan 2014; Corney and du Plessis 2010).

In work communities, the apprentice must be seen as a legitimate rather than a marginal member of the work team. Seeing apprentices in a central role also calls for the apprentices to be able to influence workplace practices and to be asked for their opinion. Virtanen et al. (2014) claim that the more apprentices see themselves as active members of their work community, the more they learn. Workplaces also provide learners with guidance through supportive practices. First of all, workplaces provide support for learners by providing them opportunities to participate in a wide range of tasks, which helps apprentices to develop broad expertise. When apprentices are rotated through different departments at the workplace, they are able to build relationships with many workers and to acquire experience from a variety of work tasks (Fuller and Unwin 2004; Savoie-Zajc and Dolbec 2003; Virtanen et al. 2014). The research shows that placing the learner in a marginal position in work communities and not seeing him/her as a legitimate member of the work team limits available learning affordances (Filliettaz 2010; Nielsen 2008; Savoie-Zajc and Dolbec 2003). The marginalized apprentice is offered only marginal tasks to work on and is continuously placed in situations that will not threaten company productivity or security (Savoie-Zajc and Dolbec 2003). This denies the apprentice the opportunity to work in important working situations and hinders the apprentice's learning of more complex and demanding tasks relevant to the development of expertise (Nielsen 2008; Savoie-Zajc and Dolbec 2003). Apprentices in marginal positions at workplaces also experience little work autonomy. Not taking the apprentice's viewpoints into account is another indicator of apprentice marginalization in the work community. Winters et al. (2009) note that students seldom receive treatment as equal partners in formal training conversations. In conversations with teachers and workplace trainers, student participation is too often limited and real dialogue seems to be lacking, as the teachers tend to dominate the themes and content of such conversations.

Communities of practice also support apprentices' learning by allowing them autonomy and independent work. Giving apprentices freedom, trust and responsibility provides them with rich learning affordances. Allowing apprentices to work independently and then praising them for a job well done substantially enhances their self-esteem (Reegård 2015). The increase in responsibility should take place gradually, with apprentices receiving more responsibility and more demanding tasks commensurate with their skills development (Evanciew and Rojewski 1999; Filliettaz 2011; Gurtner et al. 2011; Nielsen 2008; Smith 2000). Giving learners too much independence and responsibility too soon could endanger workplace guidance. Gurtner et al. (2011) argue that training apprentices to work autonomously is an important objective in many occupational sectors. Unfortunately, this objective often leads to apprentices working alone without an expert by their side. Too much independence and responsibility leads to insufficient guidance and may hinder learning (Reegård 2015). 


\section{Connectivity}

The training programs available to apprentices should be able to integrate formal and informal training, theory and practice (Onnismaa 2008; Savoie-Zajc and Dolbec 2003; Winters et al. 2009; Virtanen and Tynjälä 2008; Virtanen et al. 2014). Integrating different forms of knowledge is essential for the development of vocational competence and expertise. Students should be able to integrate theoretical information gained at school with practice at the workplace (Savoie-Zajc and Dolbec 2003; Virtanen and Tynjälä 2008; Virtanen et al. 2014). Discrepancies between learning environments might hinder the learning process (Evanciew and Rojewski 1999; Savoie-Zajc and Dolbec 2003). The integration of formal and informal learning requires close collaboration between various actors in vocational education. Moreover, guidance associated with training calls for collaboration between teachers, students and employers, which facilitates subsequent professional development. Guiding students must not be something that occurs exclusively at the workplace, though teachers often suffer from insufficient time and resources for guidance (Evanciew and Rojewski 1999; Tanggaard 2005). Teachers from vocational institutions should also be involved in helping students to set their learning goals and holding discussions with them (Virtanen et al. 2014).

The features of the training program itself have proved to be important factors of guidance affecting apprentice learning. Previous research emphasizes the importance of an explicit framework which defines clear roles and rules for the training program (Fuller and Unwin 2004; Onnismaa 2008; Smith 2000). Vocational training programs should also take into account personal needs for learning and guidance (Fuller and Unwin 2004; Onnismaa 2008; Smith 2000; Virtanen et al. 2014). Onnismaa (2008) states that the personalizing vocational studies is especially important for mature students. Having a designed apprenticeship program at the workplace that has mapped the range of tasks and skills to be covered will increase opportunities for apprentices to develop broad expertise when learning is not haphazard and productivity driven (Chan 2014; Fuller and Unwin 2004). In this way, apprentices benefit from a structured training program and clear goals (Evanciew and Rojewski 1999; Smith 2000).

\section{Conclusions}

The purpose of this review was to provide an overview of the empirical research concerning guidance and learning in the context of vocational education and training. The study has focused on identifying guidance practices, providers of guidance, and supporting and hindering factors related to guidance and learning at the workplace.

The 18 articles presented in this study illustrate different guidance practices manifested at the workplace. These practices represent both direct and indirect guidance described by Billett (2002b). Especially observations of the work environment and more experienced workers, and the allowing of independent work and explorations can be seen as forms of indirect guidance. Direct guidance on the other hand is manifested as experts and novices work closely together and engage in scaffolding activities, as information and tacit knowledge is being shared and as experts and novices engage in conversations discussing, assessing and reflecting on learning. The guidance practices that fall 
into the category of direct guidance can further be divided into (1) strategies that focus on completing certain work-related tasks (such as working together on certain tasks, giving instructions and advice, explaining and providing information) and (2) strategies that focus more comprehensively on the learning process itself (such as reflection and discussions about the things being learnt).

The articles presented in this study describe a variety of guidance practices utilized at the workplace, but also present some limitations in their use due to lack of resources or guidance awareness at workplaces. It seems that techniques that are more trainerled and easily carried out in the everyday work flow are in more frequent use, whereas techniques that require more time, reciprocality and activity from the community and learner see less frequent use., Smith (2000) for example, states that workplaces do not encourage the use of exploration because of the risk it will interfere with the company's production schedules and cause problems with workplace safety. Moreover, workplaces may already have established certain ways of doing things, and any experimenting outside these established methods may evoke an unfavorable response. When it comes to reflection, it has been proved hard for teachers to act upon the initiatives for reflection made by students at everyday work situations (Wegener 2013). Formal training for workplace trainers may also affect the chosen methods of guidance. Some studies (Evanciew and Rojewski 1999; Reegård 2015) suggest that trainers can provide guidance for learners efficiently without any formal training, whereas others (Filliettaz 2011; Smith 2000) find that structured training for workplace trainers improves the quality of workplace guidance. Nielsen (2008) and Reegård (2015) note that the independence given to learners may also sometimes result from insufficient resources for guidance rather than from intentional pedagogic strategies.

The literature shows strong evidence for the collective nature of workplace guidance, with the entire work community providing guidance and assistance for learners. Collective guidance can also come from fellow learners and be provided by other VET students at workplaces or teachers from vocational institutions. Guidance provided by members of the communities of practice invites opportunities for learners to participate in collective practices (Filliettaz 2011) by gradually taking on more responsibility and more demanding tasks as their skills develop. The learner's self-regulative skills, such as responsibility and the ability to take the initiative and actively seek guidance, affect how guidance is afforded to him/her in the work community during training. Furthermore, these skills may also affect the learner's prospects for developing expertise in future workplaces. The literature covered in this review focuses little attention on the supervisory relationship between the learner and the trainer. What seems important for learning is not the position of the person providing the learner with guidance, but a well-functioning personal relationship between the trainer and the learner as well as a commitment from both to the guidance process. Whether formally trained or not, the workplace trainer must be able to share his/her knowledge with the learner and to inspire the learner to actively participate in the learning process. The literature also discusses conditions related to the work environment, such as atmosphere, equality, legitimacy and autonomy that are considered important factors for learning. 


\section{Discussion}

The research presented in this study describes various ways through which guidance is manifested at the workplace. Students and apprentices receive close guidance in direct contact with more experienced workers, but also the more indirect forms of guidance, such as observations of more experienced workers and features of the learning context, are being described (see Billett 2002). What seems noteworthy is the rather high level of indirect guidance described in the literature (see Tables 4,5). The literature does present ways through which direct guidance is offered, but also brings forward many limitations and hindering factors for the guidance of VET students, such as lack of time and resources set aside for guidance. This raises a question about whether the indirect forms of guidance become more common in case workplaces fail at allocating adequate resources for guidance. Whether it is the resources, established ways of working and learning or the availability of pedagogical expertise that shapes guidance practices at workplaces, further research needs to evaluate the usefulness and value of these practices from a learner's point of view while taking into account the wide variation in learning environments (see Fuller and Unwin 2003) and the realities of everyday work situations.

To improve learning at work, guidance at workplaces must be part of a legitimate and established process that the broad work community is committed to providing. More attention needs to be focused on what the learner has to offer to the supervisory relationship and the skills and knowledge he/she brings to it. Even if the master-novice relationship and, in some cases, the professional monopoly on expertise remains important, the school also needs to encourage its teachers and students to cross boundaries between the school and workplace (Tuomi-Gröhn et al. 2003). Students may act as crucial change agents who carry, translate and help to implement new ideas between the educational institution and the workplace (Engeström 2011). There is a need to challenge the role of factors such as age and status in defining the concept of expert (e.g.Fuller and Unwin 2004) in order to support reciprocal learning.

A company's approach to the development of individual expertise is likely to be influenced by a range of factors, including the product market in which it is located, as well as the organization of the work and the distribution of skills (Fuller and Unwin 2004). If companies fail to map the range of skills to be covered, learning risks becoming haphazard and is more likely to be driven by the need to preserve company productivity (Chan 2014; Fuller and Unwin 2004; Smith 2000). Guidance should be recognized as an important task to be carried out at the workplace. When the processes of guidance in the work community become transparent, both learners and other members of the work community become more aware of the objectives of VET students' workplace learning, thereby supporting the allocation of adequate resources for guidance. A structured training program makes the training objectives more transparent for both the learner and the work community.

From a methodological perspective, reviewed articles used in most cases basic qualitative (e.g., content analysis) and quantitative (descriptive statistics) analysis methods. Only 11 articles contained both explanation and justification of selected methodological approach and explicit description of data analysis. In practice this means that only these studies could be properly replicated in the future. Only eight articles had a section 
about critical examination of the method(s) and limitations of the study. This is quite surprising, as all the reviewed articles were published in peer-reviewed journals. Group level data collection was applied in eight articles, but we found very little discussion about rationale of choosing such approach and related validity issues (see, e.g., Chioncel et al. 2003). Although quantitative studies in this review were based on cross-sectional design, we were delighted to see that most of the qualitative articles included components of longitudinal design (data collection varied from 1 month to 4 years). Only one study contained intervention, but that was non-controlled (retrospective). To conclude, future studies should pay more attention to methodological issues (clear argumentation why a certain design and related analysis methods were chosen; detailed description of participants, procedure and analyses) in order to minimise bias in results and recommendations.

\section{Limitations}

We want to acknowledge that, like all studies, this study has certain limitations. First, the number of articles related to workplace guidance in the context of vocational education turned out to be surprisingly small. Studies focusing primarily on guidance were rare, and in many of the studies selected for this review, guidance was something observed alongside other things, but was not the main focus. However, the cumulative results nevertheless suggest, that we managed to capture the main themes related to workplace guidance in the literature. Second, because the number of original articles that fit the inclusion/exclusion criteria was so small, we included them all in order to obtain versatile information about our topic. Thus, it is worth noting that the original articles themselves have certain limitations. In most studies, the sample size was relatively small, which is not unusual for qualitative interviews and case studies, which many of these studies represent. Although articles investigated many interesting aspects of workplace guidance, methodological robustness was not in all cases clearly opened for a reader; we found lack of detail in participant information, methodological choices and also how the analyses were conducted. This clearly limited our ability to judge importance and validity of the results and practical recommendations. Third, most of the studies featured in this paper failed either to take into account the specific features of different vocational fields or to compare the guidance afforded to learners in the different learning environments of specific vocations. Given the differences noted between different fields of vocational education (e.g. social and health care vs. technology), generalizing the results from one field to another may be questionable (Virtanen et al. 2014). Consequently, we recommend devoting more research to compare how these different field-specific learning environments affect the guidance provided to learners.

Authors' contributions

All authors participated in design of the study and writing of the research report. All authors read and approved the final manuscript.

Author details

School of Education, University of Tampere, Tampere, Finland. ${ }^{2}$ Industrial Information Management Laboratory, Tampere University of Technology, Tampere, Finland. ${ }^{3}$ Institute of Behavioural Sciences, University of Helsinki, Helsinki, Finland.

Acknowledgements

None. 
Competing interests

The authors declare that they have no competing interests.

Availability of data and materials

Data is available in anonymized form from the corresponding author upon request.

\section{Consent for publication}

Authors declare that they have approved manuscript for submission, and the content of the manuscript has not been published, of submitted for publication elsewhere.

\section{Funding}

Research was funded by Academy of Finland (Grant 303693).

\section{Publisher's Note}

Springer Nature remains neutral with regard to jurisdictional claims in published maps and institutional affiliations.

Received: 30 June 2016 Accepted: 1 April 2017

Published online: 18 April 2017

\section{References}

Aarkrog V (2005) Learning in the workplace and the significance of school-based education: a study of learning in a Danish vocational education and training programme. Int J Lifelong Educ 24(2):137-147

Akkerman SF, Bakker A (2011) Boundary crossing and boundary objects. Rev Educ Res 81(2):132-169

Akkerman SF, Bakker A (2012) Crossing boundaries between school and work during apprenticeships. Voc Learn 5(2):153-173

Billett S (2002a) Toward a workplace pedagogy: quidance, participation and engagement. Adult Educ Q 53(1):27-43

Billett S (2002b) Workplace pedagogic practices: co-participation and learning. Br J Educ Stud 50(4):457-481

Billett S (2014) Mimesis: learning through everyday activities and interactions at work. Human Res Dev Rev 13(4):462-482

Chan S (2014) Belonging to a workplace: first-year apprentices' perspectives on factors determining engagement and continuation through apprenticeship. Int J Educ Voc Guid. doi:10.1007/s10775-014-9282-2

Canfield A (1980) Learning styles inventory manual. Humanics Media, Ann Arbor, Ml

Chioncel NE, Van Der Veen RGW, Wildemeersch D, Jarvis P (2003) The validity and reliability of focus groups as a research method in adult education. Int J Lifelong Educ 22(5):495-517

Collin K, Valleala U-M (2005) Interaction among employees: how does learning take place in the social communities of the workplace and how might such learning be supervised? J Educ Work 18(4):401-420

Corney T, du Plessis K (2010) Apprentices' mentoring relationships. the role of significant others' and supportive relationships across the work-life domains. Youth Stud Aust 29(3):18-26

Engeström Y (2011) From design experiments to formative interventions. Theory Psychol 21(5):598-629

Eraut M (2004) Informal learning in the workplace. Stud Cont Educ 26(2):247-273

European Commission (2015) High-performance apprenticeships \& work-based learning: 20 guiding principles. http:// ec.europa.eu/social/main.jsp?catld=1147\&langld=fi\&moreDocuments=yes

Evanciew C, Rojewski J (1999) Skill and knowledge acquisition in the workplace: a case study of mentor-apprentice relationships in youth apprenticeship programs. J Ind Teach Educ 36(2):24-53

Filliettaz L (2010) Guidance as an interactional accomplishment. practice-based learning within the swiss VET system. In: Billett S (ed) Learning through practice. Professional and practice-based learning. Springer, New York, pp 156-179

Filliettaz L (2011) Collective guidance at work: a resource for apprentices? J Voc Educ Work 63(3):485-504

Filliettaz L, Durand I, Trebert D (2015) Learning through verbal interactions in the workplace: the role and place of guidance in vocational education and training. In: Filliettaz L, Billett S (eds) Francophone perspectives of learning through work: conceptions, traditions and practices. Springer, Dordrecht, pp 279-301

Fuller A, Unwin L (2003) Learning as Apprentices in the contemporary UK workplace: creating and managing expansive and restrictive participation. J Educ Work 16(4):407-426

Fuller A, Unwin L (2004) Young people as teachers and learners in the workplace: challenging the novice-expert dichotomy. Int J Train Dev 8(1):32-42

Fuller A, Unwin L (2011) Workplace learning and the organization. In: Malloch M, Cairns L, Evans K, O'Connor BN (eds) The sage handbook of workplace learning. Sage, London, pp 46-59

Fuller A, Hodkinson H, Hodkinson P, Unwin L (2005) Learning as peripheral participation in communities of practice: a reassessment of key concepts in workplace learning. Br Educ Res J 31(1):49-68

Gallacher K (1997) Supervision, mentoring, and coaching: methods for supporting personnel development. In: Winton PL, McCollum JA, Catletts C (eds) Reforming personnel preparation in early intervention: issues, models, and practical strategies. Paul H. Brookes Publishing Co, Washington, pp 191-214

Grant M, Booth A (2009) A typology of reviews: an analysis of 14 review types and associated methodologies. Health Inf Libr J 26:91-108

Griffiths T, Guile D (2003) A connective model of learning: the implications for work process knowledge. Eur Educ Res J 2(1):56-73

Guile D, Griffiths T (2001) Learning through work experience. J Educ Work 14(1):113-131

Gurtner J-L, Cattaneo A, Motta E, Mauroux L (2011) How often and for what purposes apprentices seek help in workplaces: a mobile technology-assisted study. Voc Learn 4(2):113-131 
Hager P (2013) Theories of workplace learning. In: Malloch M, Cairns L, Evans K, O'Connor B (eds) The SAGE handbook of workplace learning. Sage, London, pp 17-32

Illeris K (2003) Workplace learning and learning theory. J Workplace Learn 15(4):167-178

Koskela I, Palukka H (2011) Trainer interventions as instructional strategies in air traffic control training. J Workplace Learn 23(5):293-314

Lave J, Wenger E (1991) Situated learning: legitimate peripheral participation. Cambridge University Press, Cambridge Mainhard T, van der Rijst R, van Tartwijk J, Wubbels T (2009) A model for the supervisor-doctoral student relationship. High Educ 58(3):359-373

Nielsen K (2008) Scaffold instruction at the workplace from a situated perspective. Stud Cont Educ 30(3):247-261

Onnismaa J (2008) Age, experience, and learning on the job: crossing the boundaries between training and workplace. J Employ Couns 45(2):79-90

Pearson M, Brew A (2002) Research training and supervision development. Stud High Educ 27(2):135-150

Pearson M, Kayrooz C (2004) Enabling critical reflection on research supervisory practice. Int J Acad Dev 9(1):99-116

Reegård K (2015) Sales assistants in the making: learning through responsibility. Voc Learn 8(2):117-133

Savoie-Zajc L, Dolbec A (2003) Co-operative education in the pulp and paper sector in Quebec. J Workplace Learn 15(3):114-122

Scandura TA, Ragins BR, Scandura TA, Ragins BR (1993) The effects of sex and gender role orientation on mentorship in male-dominated occupations. J Vocat Behav 43:251-265

Smith P (2000) Flexible delivery and apprentice training: preferences, problems and challenges. J Voc EducTrain 52(3):483-503

Tanggaard L (2005) Collaborative teaching and learning in the workplace. J Voc Educ Train 57(1):109-122

Tuomi-Gröhn T, Engeström Y, Young M (2003) From transfer to boundary-crossing between school and work as a tool for developing vocational education: an introduction. In: Tuomi-Gröhn T, Engeström Y (eds) Between school and work: new perspectives on transfer and boundary-crossing. Pergamon Press, Amsterdam, pp 1-19

Tynjälä P (2013) Toward a 3-P model of workplace learning: a literature review. Voc Learn 6(1):11-36

Tynjälä P, Virtanen A (2005) Skill learning at work: investigations into student experiences of on-the-job learning. Learning the skills. Special edition of the Finnish Journal of Vocational and Professional Education, pp 106-116

Vehviläinen S, Löfström E (2016) 'I wish I had a crystal ball': discourses and potentials for developing academic supervising. Stud High Educ 41(3):508-524

Virtanen A, Tynjälä P (2006) Workplace learning in Finnish VET: students', teachers' and workplace trainers' perspectives. Paper presented at the EARLI SIG professional learning and development conference, 11-13 October 2006. Heerlen, the Netherlands

Virtanen A, Tynjälä P (2008) Students' experiences of workplace learning in finnish VET. European J Voc Train 44(2):200-213

Virtanen A, Tynjälä P, Eteläpelto A (2014) Factors promoting vocational students'learning at work: study on student experiences. J Educ Work 27(1):43-70

Wegener C (2014) A situated approach to VET students' reflection processes across boundaries. J Educ Work 27(4):454-473

Winters A, Meijers F, Kuijpers M, Baert H (2009) What Are Vocational training conversations about? analysis of vocational training conversations in Dutch vocational education from a career learning perspective. J Voc Educ Train 61(3):247-266

Wisker G, Exley K, Antoniou M, Ridley P (2013) Working one-to-one with students: supervising, coaching, mentoring, and personal tutoring. Routledge, New York

\section{Submit your manuscript to a SpringerOpen ${ }^{\circ}$ journal and benefit from:}

- Convenient online submission

- Rigorous peer review

Immediate publication on acceptance

- Open access: articles freely available online

- High visibility within the field

- Retaining the copyright to your article

Submit your next manuscript at $>$ springeropen.com 